\title{
Chapter 4 \\ National Immigration and Integration Policies in Europe Since 1973
}

\author{
Jeroen Doomernik and María Bruquetas-Callejo
}

\section{Introduction}

Migration of workers and refugees has long been an integral part of the European continent's history. Nonetheless, Europe's appreciation of migration as a serious societal and governmental concern is relatively recent. Among the countries with a colonial history, migration became an issue at the time of the independence of these Asian, African, and South American nations. North-Western European countries furthermore witnessed sizeable labour migration from Southern Europe, Turkey, and Northern Africa. This occurred from the 1950s into the 1970s, though it was long considered merely an issue of labour supply and demand, and not one posing social or other challenges. Only after the economic recession of the mid-1970s did migration, or rather the restriction thereof, become a topic of debate. Integration of these migrant workers and their children is an issue that took longer to arrive on the political agenda. In some countries this happened from the late 1970s; in others it came about only decades later.

From the 1990s onwards, the European countries bordering the Mediterranean, which had primarily been suppliers of labour for the growing economies of NorthWestern Europe, themselves became attractive destinations for migrants. Improvements in their economies and living conditions opened the way for the arrival of considerable numbers of workers from Central Europe, Northern Africa, and Latin America. A precondition for membership of the (then) European Economic Community was enactment of stringent migration controls; hence integration issues long took a secondary place.

The Communist Eastern Bloc had been cordoned off from the rest of the world until 1989 and had thus seen very little migration since the end of the Second World

J. Doomernik $\bullet$ M. Bruquetas-Callejo $(\bowtie)$

University of Amsterdam (UvA), Amsterdam, Netherlands

e-mail: M.D.M.BruquetasCallejo@uva.nl 
War. The main exceptions consisted of "guest workers" from socialist developing countries. These workers resided in isolation from the native populations. Vietnamese migrants remained and these days are a clear presence in the eastern parts of Germany and the Czech Republic. During the 2000s labour migration developed from farther east, such as the Ukraine, to Central Europe, while the nationals of these new destination countries themselves benefited in varying numbers from the freedom to go and work elsewhere in the European Union (EU).

From the early 1990s, refugees and asylum seekers became an issue of great urgency in North-Western Europe. Many states in this region felt overburdened and took steps to restrict asylum seekers' access to their territories and to limit asylum seekers' eligibility, thus shifting the burden to other member states. Since then, political consensus has emerged within Europe on the need for a joint approach towards asylum seekers and refugees, but so far national interests have persisted, and European solidarity on this issue has remained incomplete. More successful has been the development of EU-wide policies on migration for the purpose of family reunion and on the rights of long-term resident third-country nationals. EU law in the field of general integration policies is not on the political agenda but the Union has made efforts to stimulate social cohesion and integration of immigrants and minority groups by means of "soft" law.

In short, European countries' experiences with immigration have been diverse and related to geographical location, economic context, political history, and also to notions of nationhood, national belonging, and organization of government. Beyond these, European political integration has created an additional level of policy development, supplementing and sometimes challenging national policymaking either by subsidizing local initiatives to foster the integration of immigrants which would otherwise remain unfunded (e.g., by national governments) or by limiting objectives that are at odds with EU law (e.g., restricting nations' power to limit the rights of third-country nationals). These issues are explored further in the next two sections. The first addresses Europe's four main types of migratory experiences. The second discusses the integration policies applied in the context of these experiences. The chapter seeks to clarify how the concept of integration is used in policy formulation and policy practice, in line with the second question guiding this book: What are the main factors driving the kinds of relations observed between local governments and immigrant organizations?

\section{Immigration Experiences and National Policy Responses}

\section{Postcolonial, Labour, and Asylum Migrants in North-Western Europe}

Among the first immigrants that European countries witnessed in modern times were members of the colonial middle classes who came to the "motherland" to work or to study. Their numbers grew considerably when the colonies gained 
independence. These members of the middle classes felt uneasy under their postcolonial governments or expected a more secure future upon resettling in Europe. Although at some point these European countries of destination imposed restrictions on such resettlement, it was generally understood that these migrants belonged to the nation and that the nation had a moral obligation towards them. Even though migrants still arrive from these countries as family migrants today, postcolonial migration was predominantly from the 1950s to the late 1970s.

In the 1960s, employers in countries including Belgium, France, Germany, Sweden, and the Netherlands recruited labour from abroad. Unskilled and semiskilled workers were brought in for the service industry, construction, and manufacturing to meet the growing demands of the booming economies. At the same time, such jobs lost their attraction to native workers, whose educational levels were on the rise. The intention was to hire such workers on a temporary basis. With the exception of France, governments had no ambition to develop settlement policies (Martin and Miller 1980, 316). The term "guest worker" was used to underline this stance. Once demand for guest workers ebbed as a result of the recession following the 1973 oil crisis, facts and conceptions took diverging paths. Further recruitment was halted —in Germany by law-and the guest workers' return home seemed a logical consequence of the economic downturn. Yet a large share remained. Despite the recession, demand for their work remained sizeable (ibid., 320; Castles 1986, 765). Moreover, these workers themselves preferred to stay, as their countries of origin likewise were going through hard times. For their part, "host" governments were unable or unwilling to force their erstwhile guests to go home. Welfare arrangements and entitlements were an additional disincentive for return migration. As a consequence, many guest workers became immigrants. Because this gave cause for spouses and children to join them, the end of the guest worker era actually meant the beginning of substantially larger migration flows. As a rule, governments did not applaud this ongoing migration of family members, but their ability to curb arrivals was restricted by humanitarian, economic, and legal obligations.

The example of the Netherlands illustrates this. Some 74,000 Moroccan and Turkish workers lived in this country in 1973, but ethnic communities ten times this size arose over the next 40 years (Doomernik 2011, 73). In Germany the rise was less steep. While in 1973 the country had 910,000 Turkish inhabitants, in 2012 some 3 million German residents had a Turkish background. ${ }^{1}$

Over time, some governments acknowledged that continuing migration produced ongoing challenges in terms of integrating the newcomers into mainstream society. In no small part, this was a result of the nature of the recruitment policies, as they had been biased towards poorly educated migrants (Castles 1986, 773). The bias towards those with little formal education also put migrants' children in a disadvantaged position in education and, subsequently, the labour market (Crul and Doomernik 2003). This situation, in conjunction with an increased politicization of migration, brought about a growing interweaving of migration controls and integration requirements in countries such as Denmark and the Netherlands (from the late

\footnotetext{
${ }^{1}$ Data from Lederer $(1997,47)$ and Bundesamt für Migration und Flüchtlinge (2012, 138).
} 
1990s on). Permanent residence was made conditional on the acquisition of language proficiency and knowledge of the host country's law and society. Even though this touches all non-EU citizens, these measures were designed to target immigrants from former guest worker countries of origin. In general it can be observed that "immigration", if not directly serving the interests of the receiving states, had taken on a negative connotation in public discourse.

During the 1990s, migration from the former guest workers' countries became overshadowed-in numbers and in popular perceptions-by the arrival of large numbers of asylum seekers and refugees. In two senses this arrival resulted from the end of the Cold War. First, restrictions were removed on mobility from Eastern Europe to the rest of the world. Second, the end of the Cold War indirectly caused the disintegration of Yugoslavia and the Soviet Union. The former led to massive displacement and refugee movements. Many Bosnians ended up seeking security in Western Europe, especially in Germany, where they were given temporary protection. By 2005 the largest Bosnian populations in Western Europe were found in Austria, Denmark, Germany, Sweden, and the Netherlands (Valenta and Ramet 2011, 4). Asylum migration from the fringes of the Soviet Union, especially the Caucasus, also became significant, as did flows from Romania, Turkey, Iraq, Afghanistan, and from African states tormented by civil war and lawlessness (Castles et al. 2014, 228). These asylum seekers did not end up more or less randomly distributed among European states. They sought refuge predominantly in North-Western Europe, and within this region first and foremost in Germany. Already in 1992 the German parliament saw itself forced to alter the constitution in order to severely curtail access for asylum claimants. The effect was a drop in overall numbers, yet it also created considerable spill-over of asylum requests into neighbouring states (Grutters 2003, 165). This set in motion a dynamic by which countries sought to avoid being more attractive than others to asylum seekers, while also creating impetus for the integrated European approach that became part of the 1997 Amsterdam Treaty. Joint policies were to take effect from May 2004 at the latest.

Meanwhile two further developments took on prominence. Firstly, among policymakers a new consensus gradually emerged about the demographic and economic contributions that selective labour migration might bring. In 2000, the German chancellor proposed seeking to attract information technology (IT) specialists by means of a "green card" (Doomernik et al. 2009). The scheme was unsuccessful, but the change in rhetoric did have impact. The German government established an expert committee to rethink the hitherto dogmatic position against significant labour immigration. In other countries, such as the UK, France, and the Netherlands, soon thereafter similar schemes were devised, all geared towards attracting skilled foreign workers (ibid.). Some measured skill levels using the proxy of a high previous income (as did the UK); others applied human capital endowment measures (e.g., a university degree was used by France and the Netherlands). At the European level, too, this ambition found support and resulted in the joint Blue Card programme.

The second key development was the increasing dominance of irregular migration as a public issue. Here, North-Western Europe faced a particular challenge. 
These countries had long been characterized by inclusive welfare systems that were also open to non-nationals, alongside highly regulated labour markets in which informal labour was outlawed. This implied relative closure to immigrants, whose contribution to the economy could not be guaranteed a priori. Restrictions, however, led to situations in which an alien, for instance, upon a failed asylum request, ended up without any state support, which is diametrically opposed to the essence of the welfare state. In order to avoid such paradoxical and politically troublesome situations, these states tended to devise measures against unsolicited arrivals. At the same time, lack of legal opportunities for unskilled immigrant workers encouraged illegal migration and unwarranted asylum requests. States in North-Western Europe tended to respond with increased detention of aliens and forced return measures (Doomernik and Jandl 2008).

\section{From Emigration to Immigration in the Southern European Countries}

Once North-Western European recruitment policies were discontinued in 19731974 and the period of mass emigration from Southern Europe came to an end, Mediterranean countries began their gradual transformation to countries of immigration. Changes were spurred by unprecedented economic growth and political stability brought about by the end of the dictatorships in Portugal, Greece, and Spain, as well as by the accession of these countries to the European Economic Community during the 1980s. Spain, Italy, Portugal, and Greece presented from the beginning particular patterns of migration and migration regulation that distinguished them from North-Western Europe (Baldwin-Edwards 1997; King et al. 1997; Arango and Finotelli 2009). The "Mediterranean model of immigration" (King et al. 1997) is characterized by a predominance of labour and family migration, a scarcity of asylum seekers, illegality as an endemic feature, and the combination of restrictive admission and citizenship policies with frequent amnesties. Migration to Southern Europe is closely related to its colonial past, linked to former African and Latin American colonies, and to the opening up of Central and Eastern Europe. Similarities in migration trends and policies among these countries must thus be seen in light of their common historical developments and analogous socioeconomic conditions.

The start of immigration flows caught Southern European countries unprepared, lacking immigration experience and an adequate legal framework. Southern European countries reacted by developing policies to fence off immigration and established ius sanguinis as the principle defining who belonged to the nation. Spain passed its first foreigners law in 1985, pushed by the obligations acquired with its accession to the European Economic Community. The end of the Cold War and the gradual incorporation of Central and Eastern Europe into the EU migration system brought about a sharp increase of migration from Albania and the former Soviet Union to Italy and above all to Greece in the first half of the 1990s. In that period, 
policymakers across Europe shared a fear of an imminent "invasion" of Central and Eastern European migrants, which stimulated the introduction of stricter control and admission measures. It was in this spirit that Greece and Italy developed their first alien laws, respectively, in 1991 and 1998.

From the mid-1980s through the 1990s, Southern Europe experienced a period of intense economic growth with substantial labour shortages in low-skilled sectors. This created a strong demand for migrant labour during a time of restructuring of the global economy, resulting in a remarkable increase of foreigners' presence in Spain, Italy, Portugal, and Greece. Flows in Spain showed the most spectacular growth. The percentage of foreign population increased from 2.2 to 12.2 between 2000 and 2010, according to National Institute of Statistics figures. Despite these large flows, the issue of migration remained relatively depoliticized until recently, with foreign workers generally perceived as contributors to the national economy (except in Greece). ${ }^{2}$

As a result of the strong segmentation of the labour market that was characteristic of these countries, migrants were incorporated in low-status, low-paid jobs that natives tended to reject. Typically, those sectors with a strong need for low-skilled labour fell within the large informal economy of Southern European countries, estimated in 2002-2003 as $28.3 \%$ of gross domestic product (GDP) in Greece, $26.2 \%$ of GDP in Italy, and $22.2 \%$ of GDP in Portugal and Spain (Schneider and Klingmair 2004). Other niches of migrant labour are closely associated with the features of the Mediterranean welfare regime, particularly the large informal market for domestic work and care-giving services, which employs primarily migrant women. Gradually, governments saw the need to regulate labour migration, with Spain being the first to introduce a scheme based on a labour market test (known as the Regimen General, as established in the 1985 Foreigners Law), followed by Greece in 1991 with its invitation scheme. Ultimately, all four countries ended up introducing a system of annual quotas for labour migrants-representing all skill levels-Italy in 1990, Spain in 1993, Greece in 2000, and Portugal in 2001. These systems were a forerunner of the current EU position that recognizes the need to open new legal ways to enter the EU given the crucial role that immigration plays in the European economy. ${ }^{3}$ Implicitly, Southern European countries have bet on immigrants to maintain the low-productivity sectors that form the core of their economies (GonzálezEnriquez and Triandafyllidou 2009).

At a certain point, governments acknowledged that migration recruitment procedures were ineffective, as shown by the large presence of irregular migrants. To cope with the discrepancy between planned legal inflows and the actual needs of the

\footnotetext{
${ }^{2}$ Data from the European Social Survey between 2002 and 2008 show that while Southern Europeans are reticent towards the entry of "many" immigrants they generally acknowledge that immigrants bring about positive consequences for their national economies (Moreno Fuentes and Bruquetas-Callejo 2011, 162-165).

${ }^{3}$ In 2000, EU Commissioner for Justice and Home Affairs Antonio Vitorino declared that 'new legal ways for immigrants to enter the EU' were needed because 'the zero immigration policies of the past 25 years are not working' (cit. in Martin et al. 2006, 74-75).
} 
economy they have applied regularization programmes "ex post" with a certain degree of periodicity, though governments presented them each time as exceptional "one time only" measures (Arango and Finotelli 2009, 31). Regularizations have been applied by governments of different colour, showing a considerable continuity in the policies of the main political parties in all four countries, despite rhetorical differences (González-Enriquez and Triandafyllidou 2009; Zincone 2006). However, by 2005 regularizations had become highly controversial among NorthWestern European partners who claimed that immigrants regularized in Southern Europe tended to move to Northern Europe to benefit from the generous welfare systems there (Chauvin et al. 2013). Interestingly, research shows rather the opposite effect: regularizations in Italy and Spain have "stabilized" a large part of the immigrant population (Carafagna 2002; Blangiardo 2004; Arango and Finotelli 2009; Cachón 2007). ${ }^{4}$ In any case, from the mid-2000s, increased European integration has put more pressure on improving migration controls, and the European Council has agreed to limit regularizations to individual and ad hoc measures.

In sum, migration policies in the Southern EU member states have primarily set out to fight illegal migration. Massive migration flows to the Mediterranean countries occurred in a period combining restrictive policies and sizeable labour demand, and this partly explains why illegal migration is so predominant. ${ }^{5}$ The four Southern European countries followed a similar path of policymaking: starting with the lack of an adequate legal framework for the influx of migrants, soon after adopting strict control measures, then establishing measures to manage migrant labour, and subsequently resorting to regularizations to "repair" ex post the poorly functioning recruitment procedures.

Due to the peculiarities of the Mediterranean model of migration, illegal migration poses other challenges to Southern European countries than to North-Western European ones. Illegal migration in Southern Europe is mainly a result of visaoverstaying or losing work permits, not illegally entering the country (Monzini et al. 2006; Arango and Finotelli 2009). Southern European policymakers are thus mainly concerned with how to handle large concentrations of irregular migrants while at the same time curtailing the shadow economy and collecting taxes and social security contributions. From this perspective, regularization programmes seem to be win-win opportunities that transform irregular migrants into regular ones, making them taxpayers and social-security contributors. However, it leaves unresolved the question of how to prevent regular migrants from falling into irregularity when they have to renew their temporary residence permits and cannot prove they hold a formal job. It also fails to tackle the informal economy, which created and reproduces the South European irregular migration system.

\footnotetext{
${ }^{4}$ In fact, an Italian study observed that Eastern European citizens such as Moldavians and Ukrainians who lived in Italy had obtained their visas in Germany (Colombo and Sciortino 2004). ${ }^{5}$ Arango (2005) summarizes the factors involved in the "equation of irregularity" as intensive flows, restrictive regulations, attractiveness of the informal economy, geographical proximity, weakness of controls, and effectiveness of smuggling activities.
} 


\section{Central and Eastern Europe}

During the decades in which Eastern and Central Europe were under Communist rule migration was a rare phenomenon. Insofar as it occurred, it concerned people leaving for Western countries. There were some highly publicized cases of dissidents who managed to flee, and others who were forced into exile, but quantitatively much more important were the ethnic Germans who, by the thousands and year after year, left Poland and Romania to resettle in the German Federal Republic. Between 1950 and 1989 this led to the resettlement of, respectively, some 240,000 persons. ${ }^{6}$ After the end of the Cold War the former states of the Eastern Bloc were confronted with three challenges. The first was emigration to Western and Southern Europe. Indeed, migration triggered the fall of the Iron Curtain. Almost as soon as the Hungarian government opened its borders to Austria in the summer of 1989 large numbers of East Germans used this opportunity to travel to West Germany. Significant also was that the Hungarian government had signed the Geneva Refugee Convention thus signalling that it would not return fleeing foreigners to their countries of origin (because of the Convention's prohibition against refoulement). The desire to move West did not diminish once all restrictions on departure had been lifted. The nature of the movements did change however. Fewer people settled abroad, and forms of brief mobility and temporary labour migration took on greater importance (Favell 2008). Until the 2004 accession of 10 new member states to the EU, much of this mobility was irregular. Afterwards, it became regular as part of the EU's freedom of movement. Generally speaking, emigration from the new member states poses no policy challenges in countries of origin. The main exceptions are found in the Baltics. Upon independence in 1991, nearly half of Latvia's population was of Russian origin. This fact made development of nationality policies unavoidable. These, in effect, transformed sizeable segments of the population into foreigners, many of whom felt compelled to "return" to Russia or go elsewhere (e.g., Jews could opt for a future in Israel or Germany) (Doomernik 1997). Another consequence of ethnic state-building in the Baltics was considerable governmental concern about emigration of co-ethnics and ensuing attempts to formulate effective and inclusive diaspora policies that would ideally lead to their return once the nation's economy had recovered from its crisis (Lace 2013). In Poland, too, maintaining the diaspora's connection with the fatherland was viewed as a strategic political objective, as was the promotion of employment in the wider EU (Kicinger and Koryś 2011, 367).

Secondly, immigration, be it of refugees or workers, until today has tended to be of minor political concern. In Poland, for instance, refugee numbers have been relatively small (mainly people fleeing Chechnya) whereas most other migrants arrive for work (OECD 2013, 284). Moreover, with the exception of Hungary and the Czech and Slovak Republics net migration is negative, in Latvia and Lithuania even dramatically so (ibid., 271, 273). Early migration policies were, where needed,

\footnotetext{
${ }^{6}$ Own calculations based on Worbs et al. (2013, Table 2.2).
} 
fashioned on an ad hoc basis. Such policy responses were required towards the presence of de facto guest workers from (predominantly) Vietnam who had arrived during the Communist era. These were typically granted leave to remain. There was also regional migration to regulate from the Ukraine, Moldova, Belarus, and the Russian Federation (ibid.), but few attempts at restriction were made. This changed once accession to the EU came into view, as Kicinger and Koryś (2011) show for the Polish case. Regarding third-country nationals, directives such as those on family reunification, long-term residents, and refugees had to be turned into national law. Existing migration patterns (often of a temporary nature) from eastern neighbours were not easily reconciled with the EU logic of border management, especially the Schengen Agreement. But finally border commuting could be exempted from a strict implementation of the Schengen regime (ibid.). For labour migrants from eastern neighbouring states, simplified rules were introduced in 2006 (exempting them from labour market testing) (OECD 2013, 284). Most of these workers were employed in construction and agriculture (ibid.).

According to Čanĕk and Čižinsky (2011), reporting on the Czech experience, this happened somewhat naively and in the expectation that adopting the EU acquis would automatically mean the introduction of a comprehensive migration regime. However, the fact that this was not the case has not attracted much political attention. Since migration issues are not a salient political priority, and political parties lack distinctive positions and clear views about migration, migration policymaking has remained in the hands of specialized civil servants.

Among the Central European countries, first and foremost the Czech Republic became an attractive destination for economic migration from Russia, Ukraine, and Slovakia (Drbohlav 2012, 185). In the Czech case, increasing demand for migrant labour has been documented, especially in booming areas like Prague and Mladá Bolesvav, where some authors report that the social welfare system offers insufficient motivation for unemployed Czechs to seek work (Jíchová 2005 in Čaněk and Čižinsky 2011). Like most countries in the region, the Czech government has aspired to attract highly skilled migrant workers by means of a special scheme (Doomernik et al. 2009). Success, however, seems to have been limited (Drbohlav n.d.). In 2011, 244 migrants made use of the Czech scheme; $80 \%$ of these were Ukrainian nationals (OECD 2013, 244).

\section{Towards a European Approach to Asylum Seekers, Refugees, and Labour Migrants}

With the Maastricht Treaty of 1992, migration and asylum were formally defined as a common policy concern. As noted earlier, at the time, asylum migration stood high on the political agenda of the EU's North-Western member states. A first step towards a common approach was to limit eligibility for protection to the first safe country the asylum seeker set foot in. This principle became codified in the Dublin Convention (and was later incorporated into the EU Treaty). In effect, this put the 
obligation to receive asylum seekers on the member states at the EU's periphery. Alternative mechanisms by which to achieve more even burden-sharing have yet to be developed. Presently, some member states are unable (notably Greece) or unwilling (notably Italy) to abide by the agreements based on "Dublin". At the same time, member states farther north consider the existing arrangements as satisfactory. Political solidarity between member states is thus not easily achieved. Instead modest compensatory measures have been introduced to reward states for their efforts in accommodating refugees; the European Refugee Fund offers subsidies for their integration.

By 1997 political ambitions had progressed towards truly common policies in the field of refugee protection, asylum, and migration. The Amsterdam Treaty concluded that year (and coming into force in 1999) turned these issues into communitarian ones, and the Commission was asked to propose a comprehensive approach. By 2004 this had led in the field of asylum to directives on minimum norms regarding asylum-seeker reception and asylum procedures and on common definitions of who qualified as a refugee (which were recast in 2011). In many instances this simply permitted member states to continue existing practices. The Common European Asylum System (CEAS), as it is commonly referred to, gained new momentum from the publication in 2008 of the European Commission's Policy Plan on Asylum. This sought to build on the European political consensus regarding the need for more practical collaboration, further harmonization, and increased solidarity among member states. Yet, collaboration has since become most visible in increased border controls, the deployment of Frontex, and in 2011 the establishment of the European Asylum Support Office in Malta. Prospects for a truly joint asylum system (i.e., having joint processing facilities and redistributive measures) remain beyond the present horizon (Thielemann and Armstrong 2012).

Arguably, a common European asylum system would be born out of managerial and political necessity. However, as already noted, when the Amsterdam Treaty was drafted, the political ambition was to go much farther and devise a comprehensive European migration regime. To this end, the European Commission produced an ambitious proposal in 2001 (COMM 757/2001) going in the direction of managed and forward-looking labour immigration schemes to fulfil current and future demand and to curb irregular migration, human smuggling, and trafficking. It found support in Southern Europe but much less up north. Indeed, in subsequent steps, the willingness among member states to surrender their sovereignty in the admission of foreign workers evaporated (if it ever had truly existed).

Nevertheless, some consequential directives are now part of EU law. A 2003 directive grants long-term residents the same freedom of movement as is enjoyed by EU nationals (after five years of legal residence in one member state) (Council Directive 2003/109/EC). Also concluded in 2003 is a directive on family reunification (Council Directive 2003/86/EC) which determines the conditions under which third-country nationals can bring in their family members. In the subsequent years, this led to practices that were more liberal than some of the member states had intended. Coming into force more recently was the Blue Card Directive (Council Directive 2009/50/ EC), detailing common rules for the admission of highly skilled workers. It aims to 
simplify and standardize admission requirements for skilled workers from outside the $\mathrm{EU}$ and to ease their mobility between member states. The idea here is to increase the EU's competitive edge in the global competition for "brains". Hence, it hardly challenges member states' sovereignty (Doomernik et al. 2009).

\section{Integration Regimes: Who Is to Integrate into What and by Which Means}

\section{Integration Policies in North-Western Europe}

Since postcolonial immigration was generally understood as a collective inheritance and to comprise members of the nation, most North-Western European countries did not develop policies for the integration of migrants from the colonies. ${ }^{7}$ Nevertheless, in countries like the Netherlands, migrants were exposed to fierce re-education programmes aimed at acculturating them into the mainstream.

Migrants arriving within post-war recruitment schemes were seen as "guest workers" and therefore ideas about integrating them into society hardly surfaced. When they did, national reactions differed considerably. States varied in their basic conception of citizenship, which shapes the rules of belonging to the community. In Germany and other countries where membership to the nation is defined by descent (ius sanguinis), permanent settlement of non-Germans was politically daunting and, on the part of the migrant, required many years of patience and almost complete assimilation into society. Countries having a political definition of the nation provided easier admission of new members to the polity, as long as newcomers adhered to the constitution, laws, and political rules. Among the countries that applied such an approach to integration, some, including France, required more cultural adaptation, while others, such as Sweden, the UK, and the Netherlands, tolerated or even promoted a higher degree of cultural and ethnic diversity. Newcomers in France were considered 'individuals who had to disappear into the pre-defined political model by renouncing their own attributes — cultural, religious or otherwise-in the public sphere' (Wihtol de Wenden 2011, 67). In the UK, on the contrary, integration was officially defined as 'not a flattening process of uniformity but as cultural diversity coupled with equal opportunity in an atmosphere of mutual tolerance' (Home Secretary Roy Jenkins, cited in Rex 1995, 248). According to different ways of understanding citizenship and nationhood, European countries developed integration policies that have been coined "differential exclusionist", "assimilationist", or "pluralist". 8

\footnotetext{
${ }^{7}$ The UK, for instance, in 1965 created the Race Relations Act which outlawed racial discrimination.

${ }^{8}$ Castles and Miller's (1993) classification of conceptions of citizenship as "republican", "ethnic", or "multicultural" is one of the most frequently cited. Recent criticisms challenge the usefulness of such national integration models (Thränhardt and Bommes 2010).
} 
The timing of the development of integration policies has also been influenced by such conceptions of citizenship. For states in North-Western Europe that relied on exclusive notions of nationhood, it took a very long time to acknowledge the permanent character of migration. In Germany, for instance, the presence of nonGerman immigrants remained ignored until 2001, when a government-appointed committee concluded that migration henceforth should be actively promoted. Other countries in the region recognized relatively early on that what had seemed to be temporary migration had turned into long-term settlement. They, hence, developed integration policies and sought to limit discriminatory effects of immigration law by offering ways towards rapid naturalization. Two countries that had formulated early responses towards the settlement of non-nationals were the Netherlands and Sweden. In the Dutch case, from 1980 onward the government pursued an active integration policy whereby the precise definition of who was targeted by the policy evolved in sync with overall societal evolution. Elsewhere, realization of the permanent character of migrant settlement did not lead to formal integration policy; rather, integration was addressed under general welfare policies or shaped by less formalized arrangements and implemented by non-state actors.

Even in states that adopted explicit integration policies, the general institutional framework shaped the socio-economic integration of immigrants. Particularly, the welfare regime (and the corresponding economic-industrial configuration and type of labour market) together with immigration law have proven crucial for the position of immigrants. While the residential and legal status of immigrants determines, directly and indirectly, their access to public welfare and to the labour market as long as they remain foreigners, the distinct welfare regime in place shapes both the opportunity of access and the form and extent of benefits (Dorr and Faist 1997; Morissens and Sainsbury 2005). The systems that provide more extensive coverage for immigrants are the universal ones that include the whole residential population, like those in Scandinavian countries and, in some policy areas, in other countries (such as old-age pensions in the Netherlands and health care in Spain and the UK). Insurance systems based on contributions during times of regular employment, typical of conservative-corporatist welfare states like Germany, France, and the Benelux, tend to exclude some migrant categories from benefits. Among the selective security systems typical of liberal welfare states, such as the UK and Ireland, coverage for immigrants very much depends on the degree of governmental regulation of the market.

With time, some states that had previously excluded migrants from formal (i.e., legal) participation opened up by offering ius soli and relaxed conditions for naturalization, whereas others that were previously relatively open, started to become less inclusive in legal terms, matched by more assimilationist conceptions of "integration". Obtaining permanent residency status has in some cases been made conditional on fulfilling such integration requirements. The Dutch pioneered testing of language skills before a visa is granted to spouses seeking to join their husband or wife in the Netherlands. Upon arrival, substantial language proficiency must be demonstrated. Mandatory integration courses and contractual obligations to acquire basic language and cultural skills, first developed by Denmark and the Netherlands, 
have become widespread in this part of Europe (e.g., in France, Germany, and Austria), albeit not always aimed at the same segment of the immigrant population. In effect, admission and integration have increasingly become intertwined.

In spite of the relevance of the national level, local authorities and local actors across North-Western Europe have been and still are key in the formulation and implementation of integration policies. Even in the countries that developed highly centralized schemes, like the Netherlands and Sweden, the importance of the local level is undeniable, bringing about a distinctive view on integration oriented by rather pragmatic goals. This has sometimes led to open discontinuities or opposition between national and local policies.

\section{Integration Policies in Southern European Countries}

In Southern Europe, integration measures followed long after the attempts to regulate admissions and migrant labour. Italy launched in 1998 its first migration law including integration; Spain did so in 2000, followed by Greece and Portugal in 2001. Up to then Southern Europe's management of migration resembled in many ways that in Northern Europe during the guest worker period in the 1960s. Despite the fact that immigration to Southern Europe was neither mediated nor planned by the receiving states, a labour-oriented approach prevailed in which immigration control and labour regulation were the main priorities and integration was relegated to a second place (Bruquetas-Callejo et al. 2011). This explains the economic conception of migration that guides Southern European policies, in contrast to the humanitarian-oriented commitment that still weighs heavily in North-Western European policies (Finotelli 2009). In this view, regularizations are legitimized as a mechanism allowing the legal inclusion of formally unwanted (irregular) immigrants, provided that they enhance the utility of immigration for the receiving country's economy and society. Above all, those who contribute positively to the countries' economies become the Mediterranean answer to the question of who should be integrated.

Characteristic of Southern European countries is that integration policies have been elaborated from the bottom up, starting with local and regional initiatives in the 1990s. Policies diverged from city to city and region to region. Since the turn of the millennium, we have witnessed in all countries initiatives to produce national frameworks of integration in an effort to coordinate the policies produced at subnational levels. Greece and Portugal have been relatively successful in this regard, with national plans that are managed in a more centralized way than those in Spain and Italy. Moreover, EU initiatives and financial instruments (e.g., the European Social Fund and European Integration Fund) have promoted the application of integration projects initiated by immigrant organizations, nongovernmental organizations (NGOs), municipalities, and universities. The outcomes of these EU programmes for the promotion of the social and economic integration of immigrants have been positive though limited (Triandafyllidou 2009). 
Southern European countries have continued to think of themselves as emigration countries (Zincone 2011, 390), which is reflected in their more open integration policies. With the exception of Greece, Southern European countries are very inclusive in legal terms, especially towards migrants with a cultural or ethnic link. Regular immigrants in Southern Europe have access to basic rights (e.g., work, welfare services, health care, and education) on equal footing with natives, while irregular migrants' access depends on local authorities' will and the discretionary practices of street-level bureaucrats (González-Enriquez and Triandafyllidou 2009; Moreno Fuentes and Bruquetas-Callejo 2011). Spain is a case in point, as since 2000 irregular migrants registered in the municipal census have been entitled to basic social rights such as health care, education, and welfare allowances, although with the reform of the health care law in 2012 (Royal Decree 16/2012) health care rights were restricted to foreigners legally residing in the country and contributing to the social security system. ${ }^{9}$

As a consequence of their labour-oriented approach to migration, immigrant integration in Southern European societies takes place mainly through labour market insertion. Typical of the Mediterranean welfare regime, Southern European countries offer coverage for unemployment and old-age pensions proportionate to labour participation and contributions to the social security system. This contributive logic, which is also common among the conservative-corporatist systems of North-Western Europe, usually implies that foreign-born citizens have less coverage since they tend to hold temporary jobs. Similarly, their old-age pensions tend to be less, since most immigrants have contributed to the social security system for fewer years. Thus, Mediterranean welfare states are characterized by a combination of contributive and universal schemes. While immigrants are entitled to universal benefits in areas like health care and social services, the amount of other benefits (e.g., basic income allowances) is linked to contributions, meaning they tend to be more meagre than those of the native populations.

This also means that the process of integration is less directly mediated by explicit policies of integration but rather by immigrants' agency and interaction with local network and clientelistic relations that structure the labour market and interaction with the state in Southern Europe (Triandafyllidou 2009). Immigrants find their local niches of life and work and take part in local life and networks regardless of their legal situation. Nevertheless, as we read above, the segmentation of the labour market determines that migrants are incorporated in the less protected segments and often in very precarious situations.

Moreover, immigrants are tolerated to reside and work in these countries but are generally seen as outsiders, not belonging to the nation even after many years of residence. Restrictive citizenship policies in Southern Europe make naturalization especially difficult. Third-country nationals in Italy, Greece, Spain, and (until 2006) Portugal are required to have resided in the country at least ten years in order to apply for naturalization. Yet, for immigrants who can prove ethnic descent or colonial ties, naturalization is relatively easy, creating two differentiated roads to integration.

\footnotetext{
${ }^{9}$ Then again, regional governments are in charge of implementing this, which leads to variation. So far, several regions have publicly declared that they will not implement this reform.
} 
Southern European societies produce a different answer to the question of who should be integrated. Contrary to the North-Western European situation, Southern Europeans are rather tolerant to irregular immigrants (González-Enríquez and Triandafyllidou 2009). This can be explained by the prevailing labour migration rational, as well as the roles played by various actors. The Catholic Church in three of the four countries, for example, has lobbied for soft policies towards irregular migration (while in Greece, the Orthodox Church has not played an important role). Trade unions, too, have adopted a cooperative stance towards immigrants. While the middle classes provide a broad base of social support (partly due to the services that migrants provide for them), there are negative feelings among low-skilled workers, since their salaries and labour conditions have been affected by the arrival of immigrants.

\section{Integration Policies in Central and Eastern Europe}

The former Eastern Bloc countries still have relatively small numbers of migrants from third countries. Foreign-born residents are most prevalent in the Czech Republic at $3.8 \%$, whereas in Poland only $1.2 \%$ is foreign-born (Vasileva 2011). For Hungary the figure is $4.4 \%$, but includes many ethnic Hungarians who resettled from neighbouring countries. Accordingly, throughout Central Europe little has been done in the design of national integration policies (Dbrohlav 2012, 196). In fact, the incipient policy initiatives in this field are largely EU-driven. Central European countries' accession to the EU pushed them to develop policies in this area, despite their scant migration figures. This has implications for the policies produced, since launching integration policies in countries where there are relatively few migrants is an abstract process, and EU policymaking applies only soft measures.

In Poland, for example, integration policies have so far been limited to asylum seekers, while other categories of migrants are covered by scattered Europeanfunded initiatives. Poland's ratification of the Geneva Convention in 1991 afforded it international recognition as a democracy; therefore, refugee protection has become the most important area of integration policies (Kicinger 2009, 91). Integration policies are being articulated in the Czech Republic too, and updated yearly, with policy initiatives stressing both the acquisition of rights by foreigners and immigrants' acquisition of the Czech language and basic civic knowledge (Barsová and Barsa 2005). Since 2009, language tests have been introduced as a requirement to obtain permanent residence status. In addition, the government has since 2011 established regional integration centres where third-country nationals and refugees can find practical support. The government explicitly mentions its reliance on European resources (e.g., the European Integration Fund) to fund these centres and their activities. Writing about Poland, Stefanska (2011) asserts that without such EU funds, integration measures would be absent.

A number of these states recently reformed their naturalization laws to facilitate the legal inclusion of migrants. In the Czech Republic, for instance, five years of 
legal residence presently suffices to attain Czech citizenship. This is more liberal than the naturalization laws in Poland and Hungary. In these latter countries, respectively, ten and eight years of residence is the standard requirement, while more relaxed conditions apply for spouses of nationals and refugees. A reflection of the growing importance of migration in the Czech Republic is that from 2014 forward, naturalization will no longer require relinquishing one's original nationality.

Top-down processes of policymaking such as those promoted by EU funds may lead to inconsistencies, piecemeal policymaking, and a growing need for development of a more comprehensive integration system. In Poland, introduction of a comprehensive policy is under discussion (Pawlak 2015). In the Czech Republic responsibilities for integration policymaking are being concentrated in the Department of Asylum and Migration (Čaněk and Čižinsky 2011). In Central and Eastern Europe, overall, development of comprehensive integration policies takes place against the backdrop of the transformation of the communist regime. As any process of such deep institutional change, this transition constitutes both an opportunity for introducing new policymaking and a challenge, because brand new policies must grow in an institutional framework full of incongruities. Above all, there is a fundamental inconsistency in the logic of Central European economic and welfare institutions by which 'neo-liberal economic institutions coexist with outdated, malfunctioning distributive institutions, which are fundamentally socialist in nature' (Szelenyi and Wilk 2010, 583 in Pawlak 2015).

\section{Conclusion}

Obviously, we do not know what directions migration and integration regimes in Europe would have taken if these topics were still the sole domain of national governments. Perhaps they would have converged anyway as a consequence of other macro developments. In any event, a first general observation that can be made is that migration regimes have become similar, and where EU acquis rule, even identical. These developments have secured the position of third-country nationals and provided for uniform rules regarding family reunification. In other cases, however, convergence has not taken place along the lines of equally shared interests or fair compromise, but rather the concerns of the old EU-15 member states, particularly the North-Western ones, have set the tone. This has resulted in restrictive measures instead of burden-sharing in the EU's joint dealings with asylum seekers and refugees, to the dislike of Southern European members. With the exception of highly skilled migration, joint labour migration policies have not materialized. Furthermore, EU accession has forced member states that previously had relaxed (or few) migration policies to take controls seriously.

Convergence is furthermore in evidence when it comes to integration regimes. Countries that initially had multicultural policies have gradually developed policies with an assimilationist slant. There is also evidence of countries going in the opposite direction: from ethnically justified exclusion to more openness towards 
ethnic diversity. Those member states for which the immigration experience is fairly fresh do not tend to have comprehensive approaches towards settlers from third countries. Integration policies instead tend to be a local matter, often stimulated by EU funding. In effect, where national political agendas are less inclined towards the support of immigrant integration, these can be bypassed by municipal governments. In Central and to some extent Southern Europe, integration is not necessarily on the national political agenda to begin with. Indeed, it finds expression mainly in networks such as Integrating Cities, Intercultural Cities, CLIP (the European Network of Cities for Local Integration Policies for Migrants), and ECCAR (the European Coalition of Cities against Racism), which receive subsidies from a European Commission programme for the integration of third-country nationals. Because these networks bring together a large number of cities to work together and share practices, much of the resulting integration dynamic appears to be local.

This brings us to a third trend (and a final question): not only in new countries of immigration but also in the older member states, local governance appears to be rising in importance. As also noted by others (e.g., Barber 2013; Saunders 2010) migration is predominantly an urban affair, and local governments are keenly aware of the opportunities and challenges resulting from it. At the same time, at the national level political responses to migration can be critical, and at times downright unfriendly. This may prompt local policymakers to look elsewhere for support, for example, to the EU. Whether this actually undermines the importance of the national level in dealing with such sensitive issues as national identity and belonging is still an open question.

Open Access This chapter is distributed under the terms of the Creative Commons AttributionNoncommercial 2.5 License (http://creativecommons.org/licenses/by-nc/2.5/) which permits any noncommercial use, distribution, and reproduction in any medium, provided the original author(s) and source are credited.

The images or other third party material in this chapter are included in the work's Creative Commons license, unless indicated otherwise in the credit line; if such material is not included in the work's Creative Commons license and the respective action is not permitted by statutory regulation, users will need to obtain permission from the license holder to duplicate, adapt or reproduce the material.

\section{References}

Arango, J. (2005). La inmigración en España: Demografía, sociología y economía. In R. del Aguila (Ed.), Inmigración: Un desafío para España (pp. 247-273). Madrid: Pablo Iglesias.

Arango, J., \& Finotelli, C. (Eds) (2009). The making of an immigration model: Inflows, impacts and policies in Southern Europe. IDEA working paper number 9. www.idea6fp.uw.edu.pl/ pliki/WP_9_Southern_countries_synthesis.pdf.

Baldwin-Edwards, M. (1997). The emerging European immigration regime: Some reflections on implications for Southern Europe. Journal of Common Market Studies, 35(4), 497-519.

Barber, B. J. (2013). If mayors ruled the world: Dysfunctional nations, rising cities. Yale: Yale University Press. 
Barsová, A., \& Barsa, P. (2005). Pristehovalectví a liberální stát: Imigracní a integracní politiky v USA, západní Evrope a Cesku. Brno: Masarykova univerzita v Brne, Mezinárodní politologický ústav.

Blangiardo, G. C. (2004). L’immigrazione straniera in Lombardia: La terza indagine regionale. Rapporto 2003. Milano: Franco Angeli.

Bruquetas-Callejo, M., Garcés-Mascareñas, B., Morén-Alegret, R., Penninx, R., \& Ruiz-Vieytez, E. (2011). Immigration and integration policymaking in Spain. In G. Zincone, R. Penninx, \& M. Borkert (Eds.), Migratory policymaking in Europe (pp. 235-291). IMISCOE Research. Amsterdam: Amsterdam University Press.

Bundesamt für Migration und Flüchtlinge. (2012). Migrationsbericht des Bundesamtes für Migration und Flüchtlinge im Auftrag der Bundesregierung. Nürnberg: BAMF.

Cachón, L. (2007). La experiencia internacional en regularizaciones extraordinarias de inmigrantes indocumentados: España en el modelo del Sur de Europa. Madrid (unpublished manuscript).

Čaněk, M., \& Čižinsky, P. (2011). The case of the Czech Republic. In G. Zincone, R. Penninx, \& M. Borkert (Eds.), Migratory policy-making in Europe (pp. 327-346). IMISCOE Research. Amsterdam: Amsterdam University Press.

Carafagna, M. (2002). I sommersi e i sanati: Le regolarizzazioni degli immigrati in Italia. In A. Colombo \& G. Sciortino (Eds.), Stranieri in Italia: Assimilati ed esclusi (pp. 53-91). Bologna: Il Mulino.

Castles, S. (1986). The guestworker in western Europe: An obituary. International Migration Review, 20(4), 761-778.

Castles, S., \& Miller, M. (1993). The age of migration: International population movement in the modern world. New York: The Guilford Press.

Castles, H., De Haas, H., \& Miller, M. J. (2014). The age of migration: International population movements in the modern world. Hampshire: Palgrave Macmillan.

Chauvin, S., Garcés-Mascareñas, B., \& Kraler, A. (2013). Working for legality: Employment and migrant regularisation in Europe. International Migration, 51(6), 118-131.

Colombo, A., \& Sciortino, G. (2004). Sistemi migratori e lavoro domestico in Lombardia: Una ricerca commissionata dall'IRES Lombardia. Milan: Ires Lombardia. CEU. (2008). European pact on immigration and asylum 2008. Brussels: Council of the European Union.

Crul, M., \& Doomernik, J. (2003). The Turkish and Moroccan second generation in the Netherlands: Divergent trends between and polarization within the two groups. International Migration Review, 37(4), 1039-1064.

Dbrohlav, D. (2012). Patterns of immigration in the Czech Republic, Hungary and Poland. In M. Okolski (Ed.), European immigrations: Trends, structures and policy implications (pp. 179-209). IMISCOE Research. Amsterdam: Amsterdam University Press.

Doomernik, J. (1997). Going west: Soviet Jewish immigrants in Berlin since 1990. Aldershot: Ashgate.

Doomernik, J. (2011). The winding road past consociational democracy, multicultural society and populist rhetoric: The Dutch response to labour immigration and its consequences. OMNES The Journal of Multicultural Society, 2(2), 72-88.

Doomernik, J., \& Jandl, M. (2008). Introduction. In J. Doomernik \& M. Jandl (Eds.), Modes of migration control and regulation in Europe. IMISCOE Reports. Amsterdam: Amsterdam University Press.

Doomernik, J., Koslowski, R., \& Thränhardt, D. (2009). The battle for the brains: Why immigration policy is not enough to attract the highly skilled. Washington, DC: The German Marshall Fund of the United States.

Dorr, S., \& Faist, T. (1997). Institutional conditions for the integration of immigrants in welfare states: A comparison of the literature on Germany, France, Great Britain, and the Netherlands. European Journal of Political Research, 31, 401-426.

Favell, A. (2008). The new face of East-West migration in Europe. Journal for Ethnic and Migration Studies, 34(5), 701-716. 
Finotelli, C. (2009). The North-South myth revised: A comparison of the Italian and German migration regimes. West European Politics, 32(5), 886-903.

González-Enríquez, C., \& Triandafyllidou, A. (2009). Introduction: Comparing the new hosts of Southern Europe. European Journal of Migration and Law, 11, 109-118.

Grutters, C. (2003). Asieldynamiek. Nijmegen: Wolff.

Kicinger, A. (2009). Beyond the focus on Europeanization: Polish migration policy 1989-2004. Journal of Ethnic and Migration Studies, 35(1), 79-95.

Kicinger, A., \& Koryś, I. (2011). The case of Poland. In G. Zincone, R. Penninx, \& M. Borkert (Eds.), Migratory policy-making in Europe (pp. 347-376). IMISCOE Research. Amsterdam: Amsterdam University Press.

King, R., Fielding, A. J., \& Black, R. (1997). The international migration turnaround in Southern Europe. In R. King \& R. Black (Eds.), Southern Europe and the new immigrations (pp. 1-25). Brighton: Sussex Academic Press.

Lace, A. (2013). Why now? Analysis of the formation of Diaspora policy of Latvia. Osnabrück: M.A. thesis (MISOCO program).

Lederer, H. (1997). Migration und Integration in Zahlen: Ein Handbuch. Bonn: Beauftragte der Bundesregierung für Ausländerfragen.

Martin, P., \& Miller, M. (1980). Guestworkers: Lessons from Western Europe. Industrial and Labor Relations Review, 33(3), 315-330.

Martin, P., Martin, S., \& Weil, P. (2006). Managing migration: The promise of cooperation. Washington, DC: Lexington Books.

Monzini, P., Pastore, F., \& Sciortino, G. (2006). Schengen's soft underbelly? Irregular migration and human smuggling across land and sea borders to Italy. International Migration, 44(4), $1-25$.

Moreno Fuentes, F. J., \& Bruquetas-Callejo, M. (2011). Immigration and the welfare state in Spain. Barcelona: Fundación La Caixa.

Morissens, A., \& Sainsbury, D. (2005). Migrants' social rights, ethnicity and welfare regimes. Journal of Social Policy, 34(4), 637-660.

OECD. (2013). International migration outlook 2013. Paris: Organisation for Economic Co-operation and Development.

Pawlak, M. (2015). Research-policy dialogues in Poland. In P. Scholten, H. Entzinger, R. Penninx, \& S. Verbeek (Eds.), Integrating immigrants in Europe: Research-policy dialogues (pp. 253-274). Dordrecht: Springer.

Rex, J. (1995). Multiculturalism in Europe and America. Nations and Nationalism, 1(1), 243-259.

Saunders, D. (2010). Arrival city: How the largest migration in history is reshaping our world. London: Heinemann.

Schneider, F., \& Klingmair, R. (2004). Shadow economies around the world: What do we know? IZA discussion paper number 1043. Bonn: Institute for the Study of Labour.

Stefanska, R. (2011). Migration and integration policy. In P. Kaczmarczyk (Ed.), Recent trends in international migration in Poland: The 2010 OECD report. CMR working papers number 51/109. Warsaw: Center for Migration Research

Szelenyi, I., \& Wilk, K. (2010). Institutional transformation in European post-communist regimes. In G. Morgan, J. L. Campbell, C. Crouch, O. Kai Pedersen, \& R. Whitley (Eds.), The Oxford handbook of comparative institutional analysis (pp. 565-585). Oxford: Oxford University Press.

Thielemann, E., \& Armstrong, C. (2012). Evaluating the prospects for enhanced solidarity in the Common European Asylum System. European Policy Analysis, 15, 1-16.

Thränhardt, D., \& Bommes, M. (Eds.). (2010). National paradigms of migration research. Göttingen: V\&R Unipress.

Triandafyllidou, A. (2009). Integration and citizenship policies. In J. Arango \& C. Finotelli (Eds), The making of an immigration model: Inflows, impacts and policies in Southern Europe. IDEA Working paper number 9. www.idea6fp.uw.edu.pl/pliki/WP_9_Southern_countries_synthesis. pdf 
Valenta, M., \& Ramet, S. P. (2011). The Bosnian diaspora. Farnham: Ashgate.

Vasileva, K. (2011). Statistics in focus 34/2011. Luxembourg: Eurostat.

Wihtol de Wenden, C. (2011). The case of France. In G. Zincone, R. Penninx, \& M. Borkert (Eds.), Migratory policy-making in Europe (pp. 61-93). IMISCOE Research. Amsterdam: Amsterdam University Press.

Worbs, S., Bund, E., Kohls, M., \& Babka von Gostomski, C. (2013). (Spät-) Aussiedler in Deutschland: Eine analyse aktueller daten und forschungsergebnisse. Forschungsbericht 20. Nürnberg: Bundesamt für Migration und Flüchtlinge.

Zincone, G. (2006). The making of policies: Immigration and integration in Italy. Journal of Ethnic and Migration Studies, 32(3), 347-375.

Zincone, G. (2011). Conclusion: Comparing the making of migration policies. In G. Zincone, R. Penninx, \& M. Borket (Eds.), Migratory policymaking in Europe (IMISCOE research, pp. 378-441). Amsterdam: Amsterdam University Press. 